\title{
The Effect of Learning Method and Learning Styles Towards English Learning Outcomes
}

\author{
Riska Noviani \\ Department of Education Technology \\ Postgraduate Program Universitas Negeri Medan \\ Medan, Indonesia \\ e-mail : riska.noviani2426@gmail.com
}

\author{
Julaga Situmorang \\ Postgraduate Program Universitas Negeri Medan \\ Medan, Indonesia
}

\author{
Sugiharto \\ Postgraduate Program Universitas Negeri Medan \\ Medan, Indonesia
}

\begin{abstract}
This research aims to find out: (1) the difference between students English learning outcomes who taught using Total Physical Response Method with Direct Method (2) the difference between students English learning outcomes who have Auditory and Visual learning style (3) interaction between learning method and learning style that effect students English learning outcomes. The research method was quasi-experimental study using factorial $2 \times 2$ designs. The population consisted of 360 students in the $7^{\text {th }}$ grade of Lhokseumawe 2 State Junior High School in the first semester of 2018/2019 academic year and sample consisted of 70 students. The technique of data analysis using ANOVA two ways. The conclusion of the research are as follows (1) there is difference between students English learning outcomes which is taught using Total Physical Response Method with Direct Method. The learning outcomes of English taught using Total Physical Response Method is higher than the learning outcomes of English taught using Direct Method, (2) there is a difference between students English learning outcomes who have Auditory and Visual learning style. The learning outcomes of English of Visual learning style is higher than Auditory learning style, (3) there is significance interaction between the use of learning method and the learning style on learning outcomes.
\end{abstract} Keywords: Total Physical Response, Direct Method, Learning Styles

\section{INTRODUCTION}

Language is a medium to communicate in the implementation of learning, so that language has an important role in the intellectual, social, emotional development of students and a supporter of success in learning teaching materials. English is a worldwide language spoken throughout all parts of life such as in the arts, sciences, human sciences, travel and the social sciences. Survey English First which announced the results of the survey of English Proficiency in Indonesia in 2016 with a score of 52.91 Indonesia. This score put Indonesia in 32nd position from 72 countries surveyed globally. It shows if the English language skills of Indonesian society is still very low. Indonesia achieved lower scores compared to some of its neighbors in the region, including Vietnam in 31 st position. Another fact is seen directly in the decline in the value of subjects on the implementation of the National Exam junior level in Indonesia in 2016. As disclosed the Minister of Education and Culture in case of impairment in English subjects of 2.84 points from the previous year.

The main problem in learning English is that students have less mastery of English grammar, especially about how to compose sentences, how to use appropriate words and verbs according to time changes. Students may be able to remember all the English grammar rules when they are asked to mention the rules of grammar they were able to answer them well. However, most students difficult to express their thoughts in the form of spoken language and written language well ${ }^{[1]}$. Other facts that occur in the field in teaching and learning process teachers usually only use lecture methods, question and answer and assignment, so that student are less interested in the lessons and passive in the learning process. This condition can make students not interested in learning activities. This has an impact on student learning outcomes.

According to research from Qiu (2016) Total Physical Response (TPR) method has several advantages compared to traditional prison methods. Children are active and more relaxed in learning. The TPR method encourages students to learn English by action, so the words used in the class are most verbs or verbs with verbs of words and physical actions. During the teaching process, students are asked to do something for them. Gradually students turn to be more active in class ${ }^{[2]}$. TPR Method is the concept of teaching language developed by Prof. James J. Asher, a psychologist from San Jose State College, California, United States in the mid 60's. TPR method contains elements of the game movement so that it can relieve stress on students because the problems encountered in the lesson, especially when learning a foreign language, can also create a positive mood for students and can facilitate learning so as to increase participants' motivation and achievement learners in the lesson. Educators have an active and direct role in applying this method. Students in the TPR method have the main role as listeners and actors. Students listen attentively and respond physically to commands given 
by educators both individually and in groups. The purpose of learning the TPR method is to teach speaking skills at an early stage, using understanding as a way or way to speak, using drills (exercises) based on actions in the form of commands.

The theory related to TPR is behavioral theory. Behavioral theory is a theory developed by B.F Skinner, namely the theory that sees learning only as a result of imitation formation, practice, reinforcement, and habits. According to behaviorism, a person will show certain behaviors because of imitation. If he then receives positive feedback, this person will continue to show this kind of behavior and eventually the action will develop into a habit. Language development is seen as a result of habit formation, the view of learning becomes clear in TPR relating to the focus on the performance of the teacher and imitation by students. Learning in the view of behaviourism also says that learning is a change in behavior as a result of the interaction between stimulus and response. Skinner also explained that in learning there are a number of things that are found, namely the chance of events occurring that lead to the student's response, the learner's response, the consequences of strengthening the response ${ }^{[3]}$.

In learning English by using this TPR learning method, the material is given through direct movement or direct experience and is given repeatedly, the material provided can be in the form of an example or demonstration of the movement which is then described as a form of commands given repeatedly and then responded with physical movements by students, commands or material given repeatedly will become a habit until students understand and respond with their physical movements.

Another method used by teachers in schools is Direct Method (DM). DM first teaches oral language, the new written language is taught at a later stage. Students are immediately confronted with the sound of language and the explanation of new words not through translation or use of mother tongue, but by visualization. The Direct Method means that teaching English is given directly using the target language. That is directly pointing or showing objects, images, directly by discussing the original. So that it has an impact on many vocabulary mastery by requiring children to speak in the target language. This method was popularized in the United States by Charles Berlitz. Other aspects of the direct method are classroom teaching that exclusively uses target language, only everyday language is taught, while grammar is learned inductively ${ }^{[4]}$.

This method is good to be applied in teaching English, students can develop abilities and enrich through vocabulary obtained from everyday conversation with the original language, without having to open a dictionary, because the language used in this method is the target language. DM can create a communicative environment that encourages students to engage in the target language, and improve the development of their spoken language. The teacher must be aware of the potential of each student because this will positively influence the language development of students.

One of the things that need to be considered in the factors that influence the learning outcomes is learning style. Learning style is the way we prefer to do the activities of thinking, processing and understanding information. Each student has the style or way of learning that they like. In this case the learning style is divided into three types, namely visual (picture), auditory (sound) and kinesthetic (motion). It's just that in this study, researchers only highlighted two learning styles, namely visual and auditory. This is because kinesthetic is only suitable for certain subjects for example physical and health education subjects. Pourhossein (2012) if students of English literature at the University of Iran prefer visual learning styles. The purpose of this research is to increase faculty awareness and understanding of the influence of learning styles on the teaching process. Finding a biased learning style will allow students and teachers to determine their own personalities, their strengths and weaknesses. Teachers can enter learning styles into the classroom but before that the teacher must identify the learning styles of each student ${ }^{[5]}$.

Both research results above are also reinforced by Kumaravadivelu, according to him that the learning outcomes achieved by an individual is the result of interaction between various factors that influence it, both internal and external factors. Internal factors, including: age, characteristics, anxiety, empathy, personality, risk taking, attitude, and motivation. While external factors, such as: approaches, models, strategies and methods, learning, social environment and learning environment ${ }^{[6]}$.

In relation to the above, the purpose of this research is (1) to find out English learning result student that is taught by Total Physical Response Method is higher than the result of learning English student which is taught by the Direct Method (2) to know the difference of English learning result students who have visual learning style with English learning result of students who have auditory learning style (3) to know the interaction between learning method and student learning styles to English learning result.

\section{METHOD}

This research was conducted in Lhokseumawe 2 State Junior High School having address at Jalan Darusalam No. 1 in class $7^{\text {th }}$ grade in the academic year $2018 / 2019$. The population in this study is all students of class $7^{\text {th }}$ grade Lhokseumawe 2. The sampling technique in this research is by cluster random sampling technique, class $7^{\text {th }}$ grade $\mathrm{C}$ amounted to 36 students of the class given the learning with TPR Method and $7^{\text {th }}$ grade $\mathrm{G}$ amounted to 34 students of the class given the learning with Direct Method at Lhokseumawe 2 State Junior High School.

The method used in this research is the experimental method (quasi experiment). The research design used is the factorial design $2 \times 2$.

\section{TABLE I. RESEARCH DESIGN}

\begin{tabular}{|c|c|c|}
\hline \multirow{2}{*}{$\begin{array}{c}\text { Learning Style } \\
(\mathbf{B})\end{array}$} & \multicolumn{2}{|c|}{ Learning Method $(\mathbf{A})$} \\
\cline { 2 - 3 } & TPR $\left(\mathrm{A}_{\mathbf{1}}\right)$ & Direct $\left.\mathbf{( A}_{\mathbf{2}}\right)$ \\
\hline Visual $\left(\mathrm{B}_{1}\right)$ & $\mathrm{A}_{1} \mathrm{~B}_{1}$ & $\mathrm{~A}_{2} \mathrm{~B}_{1}$ \\
\hline Auditory $\left(\mathrm{B}_{2}\right)$ & $\mathrm{A}_{1} \mathrm{~B}_{2}$ & $\mathrm{~A}_{2} \mathrm{~B}_{2}$ \\
\hline
\end{tabular}

$\mathrm{A}_{1} \mathrm{~B}_{1}$ : English learning outcomes are taught by TPR method to students with visual learning style. 
$\mathrm{A}_{1} \mathrm{~B}_{2}$ : English learning outcomes are taught by TPR method to students with auditory learning style.

$\mathrm{A}_{2} \mathrm{~B}_{1}$ : English learning outcomes are taught by direct method to students with visual learning style.

$\mathrm{A}_{2} \mathrm{~B}_{2}$ : English learning outcomes that are learned by direct method to students with auditory learning style.

Technique data collection in this study is to use test and questionnaire techniques. The psychomotor test is used to obtain English learning result data and questionnaire to determine student learning styles. The psychomotor test is used to obtain student data of English learning result. The form of English learning result test used is practice test form. Questionnaire learning styles developed from De potter in his book. The instruments in the study used indicators in each learning style. Questionnaires are created so that students must choose the appropriate statement by giving a check list $(\sqrt{ })$.

The questionnaire scale used is likert scale with 5 choices. The instrument test is performed to obtain valid and reliable research instruments. The goal is to see whether the instrument is capable of measuring what should be measured (validity) and reliability of the instrument (reliable). It also sees the level of difficulty and distinguishing power of each item tested. In this research the experiments were conducted on the students of $8^{\text {th }}$ grade Lhokseumawe 2 State Junior High School.

Data analysis technique used is descriptive and inferential statistic technique.

To test the hypothesis, formulated statistical hypothesis as follows:

a. The first hypothesis

$$
\begin{aligned}
& \text { Ho: } \mu \mathrm{A} 1<\mu \mathrm{A} 2 \\
& \text { Ha: } \mu \mathrm{A} 1>\mu \mathrm{A} 2
\end{aligned}
$$

b. Second Hypothesis

$$
\begin{aligned}
& \text { Ho: } \mu \mathrm{B} 1=\mu \mathrm{B} 2 \\
& \text { Ha: } \mu \mathrm{B} 1 \neq \mu \mathrm{B} 2
\end{aligned}
$$

c. Third Hypothesis

$$
\begin{aligned}
& \text { Ho: } \mathrm{A}><\mathrm{B}=0 \\
& \text { Ha: } \mathrm{A}><\mathrm{B} \neq 0
\end{aligned}
$$

\section{RESULT \& DISCUSSION}

The first, second and third hypothesis testing was performed using two-way Anava. The interaction of learning method and learning style to students' learning achievement can be described below:

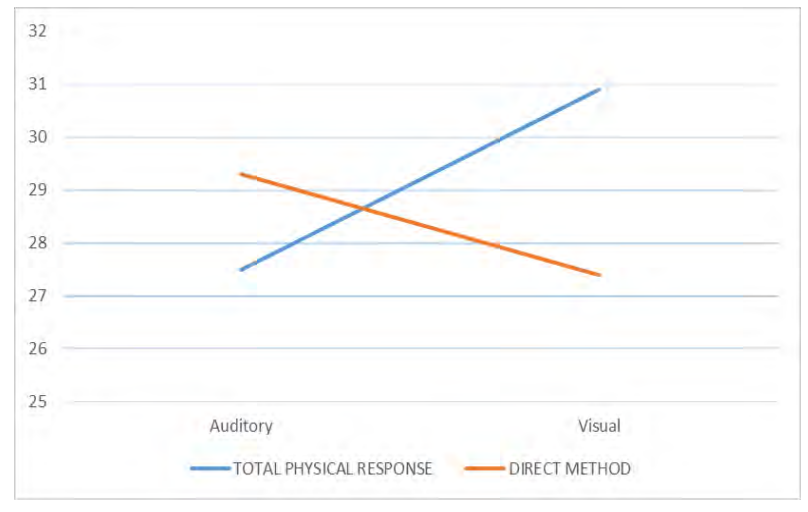

Fig 1. Interaction learning method and learning style

Based on the results of the first hypothesis testing then the results of hypothesis calculation obtained $\mathrm{F}$ calculated $=6.62$. For the distribution value $\mathrm{F}$ table $=3.9$ then this result indicates that $\mathrm{F}$ calculated $>\mathrm{F}$ table so as to give decision that $\mathrm{Ho}$ rejected and $\mathrm{Ha}$ accepted. Thus, the proposed research hypothesis that the result of learning English students class TPR method is higher than the result of learning English students class direct method.

Ice (2011) found that the TPR method was effectively used in improving English vocabulary mastery of elementary school students, especially first grade students. This can be seen from the results of the post-test experimental group which significantly increased after being treated with the TPR method, in contrast to the control group after being treated with conventional methods. The TPR method is very suitable with the children character because they like to move places and feel bored quickly if they just sit on a chair. What is more, this is supported by their good response to the TPR method. The TPR method can motivate children to be interested in learning English vocabulary because this method is very entertaining for them. This is evidenced by the feeling of pleasure and enthusiasm and often laughing when they undergo learning activities although this method can cause some students to overreact because they are too happy to participate in learning activities.

Whereas Direct method is a way of presenting foreign language learning material where the teacher directly uses the foreign language as the language of instruction, and without using the native language (in this case Indonesian) in the slightest teaching. The characteristics of this direct method are: Subject matter is first given word by word, then sentence structure, grammar is taught only as necessary, and students are not required to memorize grammatical formulas, but the main thing is students are able to speak the language well. In the teaching process always use props either in the form of direct, indirect (artificial objects) or demonstration through certain symbols or movements.

Based on the explanation above, TPR method is very effective to be used in learning English. Not only does it train students' speaking skills but TPR also trains reading, writing and listening skills well. Unlike the case with Direct Method which only focuses on the ability to speak. This results in students being less able in other areas of ability. Whereas as we know the results of learning in school are not only about 
how the language is used as a communication tool but students are also required to understand the use of grammar structure, writing language, and correct language pronunciation.

From the results of the second hypothesis calculation obtained $\mathrm{F}$ count $=5.61$. For the value of the distribution $\mathrm{F}$ table $=3.9$ then this result shows that $\mathrm{F}$ calculated $>\mathrm{F}$ table so as to give a decision that Ho rejected and Ha accepted. Thus, the research hypothesis proposed that there are differences in English learning outcomes of students with visual learning style with the result of learning English students with auditory learning style. Learning style is one of the characteristics of students' learning that must be known by the teacher. Learning style or learning style is a consistent way done by a student in capturing stimulus or information, how to remember, think, and solve problems. Learning styles that will be discussed by researchers are visual learning styles and audiotory learning styles.

People who have a visual learning style, learn by focusing on visual acuity. So for students who have a type of visual learning style, which plays an important role is the eye / sense of sight, this is due to the high need to see and capture information visually before they understand it. That is, concrete evidence must be shown first so they understand. Many visual learning styles access visual images (colors, diagrams, videos or images). To be able to understand the content of learning material, students who have a visual learning style are usually able to think using images and can learn well through vision, such as diagrams, maps, text illustrations from books, transparency, and video. This visual learning style has an influence on one's learning achievement. Whereas people who have an auditory learning style are easier to absorb information through what they listen to. The characteristics of this learning model really place the hearing / ear to absorb information or knowledge. That is, to be able to remember and understand information easily, the person concerned must hear the information / lesson first. The auditory learning style accesses all sounds and words (voice, dialogue, music or tone). That children with auditory learning styles are children who are actively speaking; he often repeats the new words he learned; he actively asks and is not easily satisfied with the "don't know" answer because he will keep asking; his emotions are easily recognizable by increasingly loud voices or the way he solves his problem by finding friends to talk; like to talk but often can't wait to hear other people talk.

Based on the explanation above, student learning style is very influential in determining learning outcomes. This is because there are different learning styles within individuals. As an educator, it is obligatory to understand the type of student learning style and provide treatment according to their type of learning style. Because if educators understand and know the type of learning style that students eat they will be able to convey the lesson properly and correctly and will achieve satisfactory results.

From the results of the third hypothesis calculation obtained $\mathrm{F}$ count $=5.50$. For the value of the distribution $\mathrm{F}$ table $=3.9$ then this result shows that $\mathrm{F}$ calculated $>\mathrm{F}$ table so as to give a decision that Ho rejected and Ha accepted. Thus, the proposed research hypothesis that there is interaction between learning method and learning styles to English learning outcomes. Teachers are not only required to know and understand the learning styles of each student but teachers are also required to understand how learning methods can be implemented in certain learning styles. The aim is that the goals or objectives of the teaching and learning process are well achieved.

Based on the explanation above learning methods and learning styles are related. Learning methods as external factors that affect student learning outcomes. As we know the results of learning are not only influenced from the outside but also from within the students themselves. Learning style is an internal factor that influences student learning outcomes. So with the choice of the correct learning method and implemented in the right learning style, student learning outcomes will increase.

\section{CONCLUSION}

First, the results of learning English in the classroom with a total physical response method is higher than the result of learning English in the classroom with a direct method in students of Lhokseumawe 2 State Junior High School.

Secondly, there are differences in English learning outcomes of students with visual learning style with students with auditory learning style.

Third, there is an interaction between learning method and learning style to English learning outcomes in Lhokseumawe 2 State Junior High School students.

\section{REFERENCES}

[1] A. Bibi. The Comparative Effectiveness of Teaching English Grammar with The Help of Textbook and by Using Group Work Activities. 2002. Islamabad: Journal of Allama Iqbal Open University.

[2] Qiu. Research on the Application of Total Physical Response Approach to Vocabulary Teaching in Primary Schools. 2016. International Journal of Arts and Commerce. International Journal of Arts and Commerce.

[3] Dimyati. Belajar dan Pembelajaran. 2010. Jakarta: Rineka Cipta

[4] Richards, J.C. Approaches and Methods in Language Teaching. 1986. United Kingdom: Cambridge University Press.

[5] Pourhossein. Visual, Auditory, Kinesthetic Learning Styles and Their Impacts on English Language. 2012. Journal of Studies in Education

[6] B. Kumaravadivelu.. Understanding language teaching from method to post method. 2006. New Jersey: LEA Publish 
